\title{
PROGRAM KELUARGA BERENCANA DALAM KAITANNYA DENGAN KEGIATAN BINA KELUARGA BALITA DI DESA BEBANDEM KECAMATAN BEBANDEM KABUPATEN KARANGASEM
}

\author{
I GUSTI NGURAH ALIT SAPUTRA \\ Fakultas Ilmu Agama dan Kebudayaan \\ Universitas Hindu Indonesia \\ alit.saputra77@gmail.com
}

\begin{abstract}
ABSTRAK
Maksud Penelitian ini adalah untuk mengetahui sejauhmana pelaksanaan Program KB melalui kelompok BKB dan permasalahan apa yang terjadi dalam penerapan koordinasi lintas organisasi perangkat Desa yang dilakukan oleh pemerintahan Desa Bebandem dalam program Bina Keluarga Balita. Tujuan penelitian ini adalah untuk mengetahui deskripsi analisis persepsi petugas tentang pelaksanaan Koordinasi lintas sektoral terkait di desa Bebandem, Kecamatan Bebandem Kabupaten Karangasem dan untuk mengetahui hambatan-hambatan yang dihadapi pemerintahan desa dalam pelaksanaan fungsi Koordinasi lintas organisasi perangkat kecamatan dan desa Bebandem.
\end{abstract}

\section{Kata-kata kunci :Koordinasi Program KB, BKB.}

\section{PENDAHULUAN}

Pemerintah Kecamatan sebagai ujung tombak penyelengara pelayanan kepada masyarakat sebagai perpanjangan tangan pemerintahan kabupaten, diharapkan mampu menterjemahkan Visi dan misi pembangunan yang diemban dalam kurun waktu tertentu sebagai upaya pencapaian arah dan tujuan pembangunan di segala bidang sebagaimana tertuang pada Rencana Starategi (Renstra) Daerah yang bersangkutan. Oleh sebab itu semua stakecholders dituntut proaktif dan bekerja keras dalam pelaksanaan pembangunan sebagaimana yang diamanatkan Undang-undang Dasar 1945 dalam upaya mensejahterakan rakyat. Aparat sebagai pelayan masyarakat saat ini dituntut adanya kerjasama antar semua pihak yang terkait guna memberikan pelayanan yang maksimal kepada masyarakat dan dengan pola yang telah berjalan, dengan menyadari tantangan pemerintahan yang berjalan.

Dalam kaitannya dengan bidang pemerintahan, usaha penyempurnaan administrasi pemerintahan pada semua level pemerintahan di tingkat bawah yang secara yuridis formal merupakan pemerintahan di bawah wilayah Kabupaten/Kota, merupakan tumpuan segenap pelaksanaan pemerintahan dan pembangunan. Untuk itu pemerintah daerah harus bertanggung jawab terhadap penyelenggaraan pembangunan di wilayahnya masingmasing dan juga harus berinisiatif, baik dalam perencanaan maupun dalam pelaksanaan pembangunan dan 
pengawasannya. Oleh karena itu untuk mencapai tujuan pembangunan di semua sektor memerlukan koordinasi dan kesungguhan dari aparat dalam melaksanakan tugas-tugas pembangunan dan menggerakkan masyarakat untuk turut serta berperan aktif di dalamnya. Pengarahan dana dan daya tenaga secara efektif dan efisien perlu dilakukan untuk menumbuhkan swadaya masyarakat karena hal itu ikut menentukan keberhasilan pembangunan sehingga dengan demikian pembangunan dengan sumber daya manusia perlu ditingkatkan secara maksimal.

Dalam peningkatan keterpaduan melalui pola koordinasi pemerintah, keterbukaan dan pemberian hak setiap kecamatanuntuk membangun daerahnya dirasakan manfaatnya untuk kepentingan masyarakat. Namun demikian tidaklah sepenuhnya harapan itu bisa dinikmati oleh rakyat seutuhnya, berbagai kelemahankelemahann dijumpai termasuk kesiapan aparatur Pemerintah Kecamatan termasuk Sumber daya manusianya dan koordinasi dengan bertumpu pada penyatuan persepsi dan integritas dalam kesatuan tindakan dan kesamaan gerak dalam bekerja ini belum maksimal, ditambah lagi adanya kecenderungan aparat dalam bekerja sering muncul perbedaan dan penafsiran dalam melihat suatu kebijakan akhirnya akan menunjukkan belum tercermin kompetensi dalam menyelenggarakan sepenuhnya roda pemerintahan secara utuh.

Berangkat dari pernyataan di atas, bahwa di dalam pelaksanaannya lembaga pemerintahan Kecamatan masih menemui beberapa kelemahankelemahan dalam penyebaran pembangunan yang tentunya dibutuhkan kesiapan dalam menjalankan berbagai aktivitas pembangunan, dan harus dipahami bahwa aparat Kecamatan dalam menjalankan fungsinya dituntut mampu mengkoordinasikan perencanaan pembangunan agar dapat seiring dengan pelaksanaan yang dirasakan langsung oleh masyarakat. Aparat telah mengemban tugas dan tanggung jawab dalam koordinasi dengan pemerintah baik pusat, provinsi dan daerah kabupaten dimana di dalamnya terdapat beberapa kelemahan-keleman dalam penyelenggaraannya termasuk kesadaran aparat akan pentingnya fungsi koordinasi itu sendiri.

Koordinasi sering kita dengar mudah diucapkan, tetapi sulit dilaksanakan.Salah satu konsep kerjasama pemerintahan yang harus dibangun dan diwujudkan ialah dengan peningkatan koordinasi dan kerjasama pemerintahan dan yang paling menonjol untuk dikedepankan pada saat sekarang, adalah konsep penanggulangan masalah kependudukan dimana persoalan ini merupakan persoalan yang dialami oleh seluruh daerah di seluruh Indonesia, bahkan di seluruh dunia.Penanggulangan masalah kependudukan merupakan salah satu program dari 8 (delapan) program dari MDGs.yang harus mendapat perhatiandalam Program KB Nasional,yaitu : Mewujudkan keserasian, keselarasan dan keseimbangan kebijakan kependudukan guna mendorong terlaksananya Pembangunan Nasional dan daerah yang berwawasan kependudukan, Mewujudkan penduduk tumbuh seimbang melalui pelembagaan keluarga kecil bahagia sejahtera.

Persoalan kependudukan adalah permasalahan global dan sifatnya multi 
dimensi,karena permasalahannya tidak bisa dipandang dari sisi jumlah penduduk saja, tetapi dari berbagai aspek. Sehingga penanganannya harus menyeluruh dan terpadu dengan melibatkan berbagai pihak. Salah satu permasalahan kependudukan yang cukup penting untuk mendapat perhatian adalah masalah keluarga berencana.Pelaksanaan Program KB Nasional ini mengacu pada visi Keluarga berkualitas tahun 2015, yakni keluarga yang sejahtera, sehat, maju, mandiri ,memiliki jumlah anak yang ideal, berwawasan ke depan, bertanggung jawab,harmonis dan bertaqwa kepada Tuhan Yang Maha Esa (BKKBN, 2007,5)

Program Keluarga Berencana Nasional yang telah dikembangkan sejak tahun 1970,saat ini telah banyak mengalami perkembangan konsep dan wawasan. Pada awalnya Program KB Nasional diarahkan sebagai upaya pengaturan kelahiran kemudian mengarah kepada pelembagaan dan pembudayaan Norma Keluarga Kecil Bahagia dan Sejahtera (NKKBS).

Dengan adanya perubahan yang telah terjadi akhir-akhir ini ,bangsa Indonesia dihadapkan dengan berbagai permasalahan baik sosial,ekonomi maupun politis yang belum juga tertangani sehingga masih ada tantangan yang berkaitan dengan lingkungan strategis ,terutama dalam mewujudkan pemerintahan yang baik. (good governance). Dengan adanya perubahan tersebut Program Keluarga Berencanan Nasionl juga harus mengutamakan aspirasi masyarakat yaitu meningkatkan kualitasnya untuk memenuhi hak-hak reproduksi dan kesehatan reproduksi sehingga dapat mewujudkan keluarga yang berkualitas.
Berangkat dari hal tersebut apa yang telah diamanatkan dalam GBHN tahun '1999-2004. Program KBN sebagai bagian integral dari pembangunan nasionmal mempunyai arah kebijakan Meningkatkan Kualitas Penduduk Melalui Pengendalian Kelahiran, memperkecil angka kematian ibu dan bayi serta Peningkatan kualitas Program KB.

Selanjutnya untuk dapat melaksanakan visi tersebut Program KBN menerapkan misi:

Pemberdayaan dan penggerakan masyarakat untuk membangun keluarga yang berkualitas, Menggalang kemitraan dalam peningkatan kesejahteraan, kemandirian, ketahanan keluarga serta meningkatkan kualitas pelayanan, Meningkatkan pelayanan KB dan Kesehatan Reproduksi.,Meningkatkan upaya-upaya promosi ,perlindungan dan upaya mewujudkan hak-hak reproduksi.,Meningkatkan upaya pemberdayaan dalam mewujudkan kesetaraan dan keadilan gender dalam pelaksanaan

Program

KBN.,Mempersiapkan

pengembangan SDM potensial sejak pembuahan dalam kandungan sampai usia lanjut.,Menyiapkan data mikro pendataan keluarga.

Dalam implementasinya pelaksanaan misi tersebut mengacu kepada Undang-undang Noomor 10 Tahun 1992. Dalam penelitian ini yang menjadi fokus perhatiuan adalah misi nomor 1 dan nomor 6 . yang pelaksanaannya dilakukan dalam kegiatan masyarakat berupa kegiatan Bina Keluarga Balita( BKB ), yang disatukan dengan pelaksanaan kegiatan Pos Pelayanan Terpadu (Posyandu). 
Program Bina Keluarga Balita (BKB), yang diintegrasikan dalam Program Keluarga Berencana Nasional merupakan program yang strategis sebagai upaya membina tumbuh kembang anak balita secara optimal dan sebagai bagian dari upaya untuk mempersiapkan keluarga yang berkualitas, yang merupakan visi program KB Nasional era baru. Dalam rangka mewujudkan hal tersebut perlu dilakukan koordinasi dan keterpaduan yang sebaik-baiknya dengan semua sektor terkait, baik yang ada di kecamatan Bebandem maupun di desa Bebandem.

Kita ketahui bersama dalam keseluruhan siklus hidup manusia, anak usia di bawah lima tahun (BALITA) merupakan periode yang paling kritis dalam menentukan kualitas sumber daya manusia, pada lima tahun pertama kehidupan manusia, proses tumbuh kembang sangat cepat. Pada masa ini disebut sebagai masa emas ("golden age period".) Apabila pada usia tersebut anak-anak tidak mendapat pembinaan dengan baik, maka anak tersebut akan mengalami gangguan perkembangan

emosi,sosial,mental,intelektual dan moral yang akan sangat menentukan sikap serta nilai pola perilaku mereka dikemudian hari, maka dari itu sangat diperlukan adanya Program Bina Keluarga Balita yang bertujuan untuk meningkatkan peranan orang tua (ayah dan ibu) serta anggota keluarga lainnya dalam mengusahakan sedini mungkin pembinaan tumbuh kembang anak balita sesuai dengan usia dan tahap perkembangan yang harus dimiliki baik dalam aspek fisik,kecerdasan emosional, maupun sosial,agar dapat tumbuh dan berkembang menjadi anak
Indonesia yang maju mandiri dan berkualitas.

Atas dasar itulah maka Peneliti melalui kesempatan ini, mencoba menelusuri permasalahan Pelaksanaan Program KB Melalui Gerakan Bina Keluarga Balita di Desa Bebandem Kecamatan Bebandem sehingga dapat diang- kat suatu penelitian sederhana dengan judul "Pelaksanaan Program KB Melalui Gerakan Bina Keluarga Balita di Desa Bebandem Kecamatan Bebandem Kabupaten Karangasem"

Berdasarkan latar belakang masalah yang telah diuraikan di atas, dapat dirumuskan dalam penelitan ini yaitu : Mengapa pelaksanaan fungsi Koordinasi organisasi perangkat desa di Desa Bebandem belum berjalan terutama dalam pelaksanaan program Bina Keluarga Balita (BKB). ?. Dampak dari lemahnya koordinasi dan Hambatan-hambatan apa yang dihadapi serta solusinya bagi pemerintah desa Bebandem kecamatan Bebandem dalam melaksanakan fungsi Koordinasi lintas organisasi perangkat Desa Bebandem dalam program $\mathrm{BKB}$ ?

Tujuan yang diharapkan tercapai dari penelitian ini, antara lain : 1) Untuk mengetahui deskripsi analisis persepsi pegawai tentang pelaksanaan fungsi Koordinasi lintas sektoral terkait di desa Bebandem ,Kecamatan Bebandem Kabupaten Karangasem dan 2) Untuk mengetahui hambatan-hambatan yang dihadapi pemerintaha desa dalam pelaksanaan fungsi Koordinasi lintas organisasi perangkat kecamatan dan desa Bebandem

Dari segi teoretis peneliti berharap hasil penelitian ini dapat memberikan tambahan ilmu di bidang pemerintahan serta ilmu sosial pada umumnya, 
sedangkan dari segi praktis diharapkan hasil penelitian ini dapat digunakan untuk bahan rujukan disetiap kecamatan dan Kabupaten dan Provinsi maupun pemerintah pusat,untuk Lembaga Pendidikan Universitas Hindu Indonesia (UNHI) Denpasar, penelitian ini diharapkan bermanfaat bagi civitas akademika UNHI, terutama bagi dosen dan mahasiswa sebagai peserta didik guna menambah wawasan penelitian, serta sebagai tambahan bahan perkuliahan, dan untuk masyarakat pada umumnya.

\section{PEMBAHASAN}

\subsection{Koordinasi Penanganan Keluarga Berencana}

Sebelum memulai suatu kegiatan operasional dalam pelaksanaan program keluarga berencana di desa Bebandem pada umumnya diawali dengan kesepakatan dalam rapat koordinasi tingkat desa yang dikenal dengan nama Rakordes. Dalam Rakordes yang diselenggarakan secara periodik/berkala akan menghasilkan kesepakatan operasinal yang akan dilaksanakan pada waktu yang akan datang, antara lain evaluasi kegiatan program Kependudukan dan Keluarga Berencana 3 bulan sebelumnya, penggalangan kesepakatan tentang rencana kerja PLKB bulan berjalan serta 2 bulan berikutnya tentang waktu,tempat,personil termasuk jadwal KIE,Pelayanan KB serta Kegiatan Tri Bina (BKB,BKR,dan BKL) termasuk Usaha Peningkatan Penghasilan Keluarga Sejahtera (UPPKS) dan juga Menyusun Rencana Kerja triwulan berikutnya. Dalam pelayanan KB sesuai kesepakatan dalam Rakordes pada umumnya masyarakat secara umum diarahkan untuk ber KB di klinik KB terdekat atau Puskesmas bagi masyarakat yang kurang mampu. Bagi masyarakat yang menghendaki pelayanan KB secara mandiri di arahkan ke klinik KB swasta atau ke Bidan Praktik Swasta dan Dokter Praktek Swasta (DBS).Ada pula sistem pelayanan yang melibatkan Tim KB keliling tingkat Kabupaten melalui sarana Mobil Unit Pelayanan KB (MUYAN) dimana tim pelaksana KB tingkat Kecamatan dan Desa sebelumnya melakukan KIE kunjungan rumah dan ada pula pelayanan $\mathrm{KB}$ tubektomi dan vasektomi yang dilakukan melalui rumah sakit daerah kabupaten Karangasem. Berikut hasil pelayanan KB Aktif di Desa Bebandem pada bulan Agustus sampai Oktober 2014.

Tabel 2.1., Hasil Pelayanan KB Aktif di Desa Bebandem bulan Agustus 2014.

\begin{tabular}{|l|ll|l|l|l|l|}
\hline No & Uraian & $\begin{array}{l}\text { Pelayanan } \\
\text { Pemerintah }\end{array}$ & $\begin{array}{l}\text { Pelyn } \\
\text { Swasta }\end{array}$ & $\begin{array}{l}\text { Seluruh } \\
\text { Tahapan }\end{array}$ & $\begin{array}{l}\text { Pra S.KS } \\
\text { I }\end{array}$ \\
\hline 1. & Jml PUS & - & - & 1832 & 1169 \\
\hline 2. & $\begin{array}{l}\text { Jml.Peserta } \\
\text { Aktif } \\
\text { a.IUD }\end{array}$ & 647 & 902 & 1549 & 990 \\
b.MOW & 368 & 540 & 908 & 576 \\
& 82 & 0 & 82 & 49 \\
\hline
\end{tabular}




\begin{tabular}{|l|l|l|l|l|l|}
\hline & c.MOP & 13 & 24 & 37 & 32 \\
d.Kondom & 32 & 2 & 34 & 11 \\
e.Implant & 118 & 220 & 338 & 284 \\
f.Suntik & 31 & 116 & 147 & 35 \\
g.Pil & & & & \\
\hline 3 & $\begin{array}{l}\text { PUS bukan Peserta } \\
\text { KB }\end{array}$ & - & - & 283 & 179 \\
a.Hamil a.Ingin anak segera & - & - & 58 & 32 \\
b.Ingin anak ditunda & - & - & 70 & 31 \\
d.Tdk.Ingin anak & - & - & 85 & 60 \\
lagi & - & 70 & 56 \\
\hline
\end{tabular}

Sumber : Rek.Des.F/I/Dal/10.

Jika diamati kesertaan ber KB masyarakat Desa Bebandem ternyata dari 1549 peserta KB aktif mayoritas menggunakan Alat Kontrasepsi Dalam Rahim (AKDR) yaitu sejumlah 908 $(58,62 \%)$ dan dari jumlah itu sebanyak 990 dari keluarga Pra S. dan KS I sedangkan dari seluruh tahapan KS sebanyak 908 tersebut 576 atau 63\% dari keluarga Pra S. dan KS. I , ini menandakan kesertaan ber KB masyarakat cukup mantap. Pilihan alat kontrasepsi selanjutnya yang dominan dipilih masyarakat adalah Suntikan yaitu sejumlah 338 akseptor dan dari jumlah itu 284 dari keluarga Pra S.dan KS I. Selanjutnya disusul pengguna KB Pil 147,MOW 82,Pil 147,MOP 3,Kondom 37 dan implant 34.

Jumlah PUS yang tidak ber KB hanya $283(15,45 \%)$ dari 1832 Pus yang ada karena ada yang hamil 58, ada yang ingin anak segera, ada yang ingin anak namun menunda dan sebanyak 70 Pus tidak ingin anak lagi. Dan bila diamati alasan Pus Pra S. dan KS.I.tidak ber KB sebanyak 32 hamil, 31 ingin anak segera,60 ingin menunda anak dan 56 tidak ingin anak lagi.

\subsection{Koordinasi Penanganan BKB}

Sesuai juga dengan kesepakatan dalam Rakordes biasanya jadwal pelaksanaan kegiatan kelompok Bina Keluarga Balita (BKB) diatur setiap bulan yang disinkronkan dengan pelaksanaan Posyandu. Pelaksanaannya dikoordinasikan oleh Tim Tingkat Kecamatan yang terdiri dariyang terdiri dari Puskesmas,Petugas keluarga Berencana,dan petugas dari PMD.yang telah terjadwal setiap bulan. Sesuai dengan fakta yang peneliti dapatkan di daerah penelitian, pelaksana kegiatan BKB setiap bulan dilakukan oleh Kader $\mathrm{BKB}$ atas pengawasan dan pembinaan Kepala Dusun dan PLKB yang mewilayahi Desa Bebandem dan pada saat yang pelaksanaannya disinkronkan 
dengan kegiatan Posyandu dengan sistem 5 meja yaitu : Meja 1 Pendaftaran balita, ibu hamil, ibu menyusui, Meja 2 Penimbangan balita,Meja 3 Pencatatan hasil penimbangan, Meja 4 Penyuluhan dan pelayanan gizi bagi ibu balita, ibu hamil dan ibu menyusui, Meja 5 Pelayanan kesehatan, KB, imunisasi dan pojok oralit

Pelaksanaan kegiatan ini memerlukan penurunan masyarakat yang dimotori oleh kepala dusun/klian banjar, karena juga melibatkan keluarga-keluarga yang mempunyai anak Balita. Adapun pelaksana dalam kegiatan BKB ini adalah kader sedangkan peserta atau anggotanya adalah orang tua dan anggota keluarga lainnya yang memiliki anak Balita umur 0 - 5 tahun dan usia pra sekolah 5-6 tahun.

Dalam penentuan kader ini dilakukan oleh PLKB dengan berkoordinasi dengan Kepala Dusun dengan syarat anggota masyarakat setempat mau bekerja dengan sukarela membina dan menyuluh orang tua balita tentang bagaimana mengasuh anak secara baik dan benar,dapat membaca dan menulis dan juga mampu berkomunikasi dengan orang tua Balita secara baik. Tabel berikut menggambarkan hasil pelaksanaan kegiatan BKB di Desa Bebandem dalam bulan Agustus 2014.

Tabel 2.2

\begin{tabular}{|l|l|l|l|}
\hline No. & Kegiatan & Jumlah & Ketr. \\
\hline 1. & Jml.Kel.yg menjadi sasaran Poktan & 73 & - \\
\hline 2. & Jlm kelg.yg menjdi anggota Poktan & 58 & - \\
\hline 3. & $\begin{array}{l}\text { Jml kelg.yg mnjdi anggota Poktan aktif dlm } \\
\text { pertemuan. }\end{array}$ & 58 & - \\
\hline 4. & Jml anggota Poktan yg berstatus PUS & 58 & - \\
\hline 5. & Jml anggota Poktan yg berstatus Pus Pra S.da KS.I & 58 & - \\
\hline 6. & Jml Pus anggota Poktan yg menjadi Peserta KB . & 48 & - \\
\hline 7. & $\begin{array}{l}\text { Jml Pus Anggota Poktan yg menjadi Peserta KB Pra } \\
\text { S.dan KS I }\end{array}$ & 48 & - \\
\hline 8. & Jumlah Pertemuan /Penyuluhan Poktan & 4 & - \\
\hline 9. & $\begin{array}{l}\text { Jumlah kelg.yg menjadi anggota Poktan BKB yg } \\
\text { menggunakan KKA }\end{array}$ & 58 & - \\
\hline
\end{tabular}

Sumber : Rek.Des.F/I/Dal/10.

Berdasarkan tabel tersebut dari 73 jumlah keluarga sasaran kelompok kegiatan yang baru menjadi anggota kelompok sejumlah 58 keluarga dan secara aktif hadir dalam pertemuan ataupun penyuluhan. Dan kesemuanya berstatus sebagai Pasangan Usia Subur (PUS), dan semuanya tergolong

\section{VIDYA WERTTA}

Vol. 1 Nomor 2, Oktober 2018 
keluarga Pra Sejahtera dan Keluarga Sejahtera I. Sedangkan yang menjadi peserta KB 48 orang dari jumlah itu semuanya tergolong Pra S.dan KS.I. Volume pertemuan/penyuluhan dalam sebulan 4 kali dan semua anggota telah menggunakan Kartu Kembang Anak (KKA).

\section{PENUTUP}

Pada bagian akhir dari laporan penelitian ini, maka peneliti dapat menyimpulkan dari apa yang peneliti temukan di daerah penelitian, adalah sebagai berikut: Pada hakekatnya secara umum koordinasi yang dilaksanakan di daerah penelitian sudah dilakukan,

\section{DAFTAR PUSTAKA}

Alfred R.Latiener,1985.'Teknik Memimpin Pegawai dan Pekerja ". Aksara Baru. Jakarta

Efendi Taufik, 1995, Dasar-Dasar keterampilan Abdi Negara Melayani Masayarakat, Bumi Aksara, Jakarta.

BKKBN,2007, Bahan Penyuluhan Bina Keluarga Balita Pengasuhan dan Pembinaan Tumbuh Kembang Anak,BKKBN,Jakarta.

Farid Ali,2001 Teori dan konsep Administrasi, dari pemikiran paradigmatik menuju redefensi, Raja grafindo Persada Jakarta

Gaspersz Vincent (Eds,,), Indonesia "Manajemen Kualitas; Penerapan Konsep Kualitas Dalam Manajemen Bisnis Total", Gramedia Indonesia

G.R.Terry dan Rule,L.W.2003 “ Dasardasar manajemen"Terjemahan Ticoula G.A. Bumi Aksara. Jakarta berawal dari penyusunan perencanaan, kemudian digodog lewat Musrenbang, dari tingkat Desa, Kecamatan dan tingkat Kabupaten. Masing-masing Satuan Kerja Perangkat Daerah (SKPD) sudah menyusun rencana kerja (Renja) sesuai dengan mekanisme yang telah ditentukan dalam Petunjuk Pelaksanaan ( juklak) dan Petunjuk Teknis (juknis). Evaluasi terhadap pelaksanaan kegiatan kurang dilakukan, sehingga hampir setiap tahun hal serupa selalu terjadi, yaitu masing-masing Tim yang berasal dari masing-masing SKPD nampaknya masih berjalan sendiri-sendiri di dalam mengaplikasikannya kepada masyarakat.

Ibrahim, Soewarno, 1997, Pengantar Studi Ilmu Administrasi dan Manajemen, PT Gunung Agung, Jakarta

Soewarno Handyaningrat, Adminsitrasi Pemerintah Dalam Pembangunan Nasional,Jakarta : PT Gunung Agung, 2002, hlm. 117

Suparta,Nyoman, 2011. "Strategi Efektif Penanggulangan Kemiskinan" Pustaka Nayottama, Denpasar.

The Liang Gie. 1992 " Administrasi perkantoran Moderen" Yogyakarta, Libreti

Tjokroamidjojo, Bintoro "Perencanaan Pembangunan" PT. Gunung Agung, Jakarta

Undang-Undang Republik Indonesia No: 10 Th 1992, UU RI No:10 Th 1992 Tentang Perkembangan Kependudukan dan Pembangunan Keluarga Sejahtera, Jakarta ; BKKBN. 


$\begin{array}{cr}\text { Undang - Undang } & \text { N0: 52 } 2009 \\ \text { Tentang } & \text { Perkembangan } \\ \text { Kependudukan } & \text { dan }\end{array}$

Pembangunan Keluarga.Jakarta ;BKKBN.

Vol. 1 Nomor 2, Oktober 2018 